remain in bed throughout the period, omitting iron, and taking instead about roo grains of calcium lactate a day, supported if necessary by injections of cotarnine hydrochloride. After a few months the periods settle down to a normal amount and duration. Menorrhagia is common again about the climacteric. Although not the prime cause of the anaemia, for the patient has previously suffered from anaemia and scanty menstruation, it may nullify all haematinic therapy. It is unwise to wait too long for a natural menopause, as this may condemn the patient to years of invalidism. Treatment by $x$-ray or cubtotal hysterectorny should be recommended early; the results are extremely good.

\section{Anaemia in Men}

Little can be said about anaemia in men. It is usually of short history, responds rapidly to large doses of iron, and rarely relapses. The cases are equally divided into a group in early life with normal gastric secretion and no symptom except anaemia, ${ }^{1954}$ and a group in later life with simple achlorhydric anaemia. It may be noted in conclusion that although simple achlorhydric anaemia occurs with greatest frequency in women in the roproductive period, a small but important number of cases occur in old people of either sex. ${ }^{10}$

\section{SUMMARY}

I Chronic microcytic anaemia, for which none of the usual causes of secondary anaemia can be found, occurs with considerable frequency in women of reproductive age. The women affected are generally of asthenic constitution, and achlorhydria is present in 80 per cent.

2 The anaemia is chronic and shows little or no tendency to improve until after the menopause, when it may disappear spontaneously.

3 The spleen is palpable in one-third of the cases, but recedes beneath the costal margin on repair of the anaemia.

4 Superficial glossitis, indistinguishable from the sore tongue of pernicious anaemia, is present in one-half of the cases. Stomatitis also occurs. In about 15 per cent. the inflammation spreads to the pharynx, producing dysphagia, which may be the presenting symptom.

5 Treatment is simple and effective. All cases respond to iron, provided it is given by the mouth in large doses for an adequate period of time. Liver is of no value. Owing to the risk of relapse, it is advisable to continue a small maintenance dose of iron after the anaemia has been cured.

\section{NOTE ON THE LITERATURE}

I have reviewed the literature in previous papers. ${ }^{53} 54585837$ Subsequent descriptions of chronic microcytic anaemia are listed below..$^{13} 26_{27} 32$ I had previously overlooked West's paper ${ }^{48}$ which was published under Dr. A. F. Hurst's direction in 1928, and which must be one of the earliest English descriptions of uncomplicated simple achlorhydric anaemia. Naegeli ${ }^{\text {s4 }}$ gives an admirable short account of these anaemias in the last edition of his textbook, regarding them as variants of chlorosis and stressing the constitutional basis. I have to thank Professor A. W. M. Ellis, of the London Hospital, and the physicians of Guy's Hospital, for the opportunity of studying patients under their care. I am indebted to the members of the Will Edmonds Committee for Clinical Research, and especially to Dr. A. F. Hurst, for much advicc, encouragement, and assistance.

'Albu, A.: Therapie der Gegenwart, 1913, liv, 433

2 Barber, H. W.: Guy's Hosp. Reports, r93i, lxxi, 92

${ }^{3}$ Bedingfield, H.: Visceroptosis and Chronic Invalidism, Oxford University Press, London, I930

'Bland, P. B., Goldstein, L., and First, A.: Amer. Journ. Med. Sci., I030, clixxix, 48.

'Bulleid, A.: Guy's Hosp. Reports, 1931, Lxxxi, I16.

- Cameron, M.: Journ. of Laryngol. and Otol., 1929, xliv, 168.

'Campbell, J. M. H.: Guy's Hosp. Reports, 1923, lxxiii,' 247.

${ }^{8}$ Conner, H. M.: Journ. Amer. Med. Assoc., 1930, xciv, 606 .

- Cornell, B. S.: Pernicious Anaemia, Durham, U.S.A., I927.

10 Davies, D. T., and James, T. G. I.: Quart. Journ. of Med., 1930 xxiii, $\mathrm{I}$.
"Douthwaite, A. H.: Lancet, 1931, i, 785

12 Elwyn, H.: Edema and its Treatment, New York, 1920, 137.

${ }^{3}$ Giffin, H. Z., and Watkins, C. H.: Jou'n. Amer. Med. Assoc., 1929, xciii, 1365, and 1930, xcv, 587 .

${ }^{14}$ Gordon-Taylor, G., and others: Brit. Journ. of Surg., 1929, xvi,

$64 \mathrm{I}$.
Graham, G., and Johnson, R. S.: Quart. Journ. of Med., xxiv, January, I931.

${ }_{17}^{16} \mathrm{Gram}, \mathrm{H} . \mathrm{C}$. : Folia Haematol, 1930, xxxix, $46 \mathrm{r}$

Hahn, A. G.: Forty-fifth Annual Report, Trudeau Sanaterium, 1929, 876 .

is Heyn, W.: Dermatol. Zeit., 1026, xlvii, 132

${ }^{12}$ Hill, H. G.: Quart. Journ. of Med., xxiv, January, s93r.

${ }_{20}^{20}$ Hurst, $\Lambda$. F.: 'Gity's Hosp. Reports, 1926, lvxvi, 426.

Jungmann, P.: Klin. Woch., 1922, i, 1546.

2 Kaznelson, P., Reimann, F., and Weiner, W.: Ibid., I92n, vii, 107r. ${ }^{23}$ Kecfer, C. S., and Bloomfield, A. L. : Bull. Johns Hoplinins Hosp., 1926, Xxxix, 30.

${ }^{24}$ Kieefer, C. S., and Yang, C. S. : Nat. Med. Journ. China, 1929, Xv, $70 \mathrm{r}$.

is J,ewis, G. E.: Practitioner, 1930, cxxv, 749

${ }^{26}$ McCann, WV. S., and Dye, J.: Ann. Int. Vcd., 1931, iv, 918.

${ }_{23}^{27}$ IcLester, J. S.: Journ. Amer. Med. Assoc., 1930, xcv, 719.

${ }_{28}^{28}$ McNee, J. W.: Glasgow Med. Journ, 1929, cxi, 193.

${ }^{29}$ Maver, ir. B.: Journ. Amer. Med. Assoc., 1920, lxxiv, 03.

Mettier, S. K., and Minot, G. R.: Amer. Journ. Med. Sici, 193r, clxxxi, 25.

${ }_{32}$ Meulengracht, E.: Ibid., 1925, clixix, 177

${ }^{32}$ Mills, E. S.: Canadian Med. Assoc. Journ., 1930, xxii, 175.

${ }^{33}$ Moersch, H. J., and Conner, H. M.: Arch. of Otolaryng'ol., 1926, iv., I12.

- Blutkrankheiten und Blutdiagnostik, 5 th Edition, Berlin, 1931.

${ }^{35}$ Pemerton, R. Arthritis and Rheumatoid Conditions, Philadelphia, 1929.

${ }^{36}$ Polland, W. S., and Bloomfield, A. L.: Joum. Clin. Investisation, I93I, ix, 65I.

${ }^{37}$ Powers, J. H., and IIurphy, W. P.: Journ. Amer. Mcd. Assoc., 193I, xcvi, 504

${ }^{31}$ Poynton, F.. J., and MacGregor, J. V.: Lancet, 1930, ii, 2.40.

${ }^{30}$ Riecker, H. H.: Arch. Int. Mled., i930, xlvi, 458.

${ }^{20}$ Schneider, J. P., and Carey, J. B.: Alimnesota Mcd., 1927, x, 2r.4.

"Seppänen, A.: Acta Med. Scandinav., 1930, Supplenent. xxxiv. 127.

${ }^{4}$ Skolnik, E. A.: Arch. Derm. and Syph., 1930, xxii, 642.

"Saughan, J.: Proc. Roy'al Soc. Med., I931, xuiv, 924.

"Warburg, E. J., and Jorgensen, S.: Acta Mcd. Scardinav., =928, lixix., 537, and $1 \times x$, 193 .

${ }^{4}$ laix., 537, and lxx, I93.

to Wcber, F. P., and Scholtz, M.: : Proc. Royal Soc. Ned., 1930, xxiv, I49, and 193I, xxiv, 923 .

6. Weiner, W., and Kianelson D. Folia Hacmatol 1026, xxxii, 233

4 West E. M. B.: Guv's Hosp. Reports, 1928, lxxviii, 484

“Wilkinson, J. F.: British Medical Journal, 193I, i, 85.

so Wilkinson, J. F., and Brockbank, W.: Quart. Journ of Med., 1931, xxiv, 219.

sI Wilkinson, J. F., and Oliver, T. H.: Lancet, 1931, i, 66

${ }^{52}$ Wills, L., and Talpade, S. N.: Indian Journ. Mcd. Rescarch, 1930, xviii, 283.

${ }^{2}$ Witts, L. J.: Guy's Hosp. Reports, 1930, 1xxx, 253.

54 Idem: Ibid., 1930, $1 \times x \times, 417$.

so Idem: Ibid., 1931, lxxxi, 193.

67 Idem: Proc. Royal Soc. Med., 1931, xxiv, 543.

"Zamorani, V.: Clinica Pediatrica, 1930, xii, 1095, Ref. Jeirn. Amer. Acd. Assoc., 193I, xcvi, 903.

\section{SIMPLE ACHLORHYDRIC ANAEMIA TREATED BY IRON}

BY

\section{C. HARE, M.D., M.R.C.P.}

PHYSICIN, ROYAI. FREE HOSPITAL

Simple achlorhydric anaemia has emerged slowly as a definite entity from among the group of secondary anaemias, and it is remarkable that general recognition of the condition has been so long delayed. A valuable paper on the subject was published by L. J. Witts ${ }^{1}$ in 1930 , with an analysis of fifty cases and full references to the literature; more recently prominence was given to the subject in a discussion on iron therapy at the Royal Society of Medicine. ${ }^{2}$

The subject is of importance and interest for the following reasons. (a) There is reason to believe that this anaemia is a modern disease; a study of the literature on blood diseases of the past century reveals no clinical description of the present type. It somewhat resembles chlorosis, but can be sharply defined from it. (b) The 
etiology of the condition is of great importance. The anaemia is associated with a chronic gastritis, to which the achlorhydria may be secondary, as emphasized by D. T. Davies. ${ }^{2}$ (c) The condition is not uncommon in women in the fourth and fifth decades of life, but it appears probable that the majority of the patients go unrelieved, being insufficiently dosed with iron, or treated with liver and stomach extracts which have no curative effect.

\section{Description of the Disease}

From the clinical aspect it may be described in general terms as an anaemia of insidious origin and great chronicity, affecting females almost exclusively, and developing between the ages of 30 and $\mathbf{4 0}$ years. There is usually no close association with haemorrhage or sepsis, but it is frequently accompanied by gastro-intestinal lesions, such as stomatitis, fissures at the angles of the mouth, glossitis, pharyngitis, gastritis, and occasionally colitis, producing the symptom-group of the PlummerVinson syndrome. Palpable enlargement of the spleen is sometimes present; other symptoms and physical signs are such as are secondary to the anaemia-breathlessness, palpitations, giddy and fainting attacks, and cardiac dilatation.

From the laboratory aspect the condition is an anaemia of chlorotic type-a haemoglobinaemia. There is no evidence of blood destruction within the tissues. The red cell count is often but little reduced, and may be normal even before intensive treatment; during treatment an erythrocytosis commonly develops. The cells show anisocytosis with many microcytes at first, but appear to be of normal average size during a remission. The colour index may be extremely low during the untreated phase, and tends to remain subnormal throughout. The fractional test meal shows achlorhydria or hypochlorhydria; there is usually excess of mucus.

\section{Differential Diagnosis}

The differential diagnosis of chlorosis and simple achlorhydric anaemia is of interest. The blood picture of the two anaemias is practically identical ; but a comprehensive article on chlorosis by Sir Clifford Allbutt ${ }^{3}$ in 1898 gives no description of a clinical type which can be made to include simple achlorhydric anaemia, nor can it be recognized under any other heading. It is unbelievable that an anaemia of such definite clinical characteristics could have escaped the acute observers of the end of the last century. Chlorosis was then so common that, to quote from Allbutt, "It was well known in every consulting room, public or private " ; it was " no respecter of race, rank, or fortune" ; " a disease of country and of town girls" ; and so predominantly a disease of virgins that Dr. Lloyd Jones, who had made a special study of the subject, is quoted as saying that in twenty years of practice he had only seen two cases in married women, and both of those were domestic servants who had never borne children. Some cases of chlorosis are indeed described as persisting into middle life, with frequent relapses; but there is no doubt that the simple achlurhydric anaemia of the present day is not a persistent chlorosis. The age of onset of simple achlorhydric anaemia in Witts's series is in the fourth or fifth decade in 70 per cent., and his youngest patient is 22 years old. The married women in the present series have all borne children (six cases, with twenty-five children). A norınal acid gastric secretion is reported to be present in chlorosis; this is mentioned by Allbutt and by more recent writers.

The resemblances between the two diseases are $(a)$ the blood picture, (b) the sex incidence, $(c)$ the tendency to relapses, and $(d)$ the cure or permanent remission which follows continued treatment by large doses of iron. The differences lie in $(a)$ the age incidence, $(b)$ the relation to sex activity and fecundity, and $(c)$ the gastric secretions. Lastly, there is the striking fact that during the last thirty to forty years chlorosis has been disappearing, and a formerly unknown type of anaemia has appeared.

\section{Therapeutics}

The disease appears to be one of severe iron deficiency, and only a moderate increase of haemoglobin is found after administration of iron preparations in the official pharmacopoeial doses. In Case II, after eight months' treatment, haemoglobin was 56 per cent. In Case I, after four months, haemoglobin was 68 per cent., but the response was probably assisted by a blood transfusion at the beginning of the period; three months later the haemoglobin had fallen to $\mathbf{5 0}$ per cent. The following treatments were given without apparent benefit. Injections of iron and ammonium citrate up to $1 \frac{1}{2}$ grains daily. Arsenic was given in Cases II and III. Liver, half a pound daily for considerable periods, in Cases I, II, III, and IV. Hydrochloric acid was given to most of the patients. Stomach lavage was performed daily with hydrogen peroxide in Cases IIr and IV, for periods of seventeen days and six weeks respectively. Blood transfusions were given to two patients. In Case $I$, two transfusions at intervals of nine months were followed by temporary improvement; in Case IV one transfusion was done. The improvement appears to last from two to three months.

As will be seen from the records below, in Cases $\mathbf{I}$ to $\mathbf{v}$ the patients had been under observation and treatment for a considerable time before massive iron dosage was given. Some had improved and relapsed again, but in none had the blood condition reached normal ; the haemoglobin was still below 60 per cent. in all the cases when massive iron dosage was begun. The rise in the months following was so striking that it is difficult to believe that it is to be attributed to the cumulative effect of the previous treatments. In Case vi there had been no previous treatment, and the results were equally impressive. In Case IV smaller doses were given than in any of the other cases, and the maximum rise of haemoglobin was the lowest shown. In Case IX no regular treatment was given ; this demonstrates the fact that the anaemia shows no tendency to spontaneous remission. The results are uniform except in Case viII ; the complete failure of haemoglobin response to treatment suggests that the case belongs to a different category, though the clinical findings appear similar. The tendency to relapse is shown by Case III, in which no treatment was given for ten months, when the haemoglobin was found to have fallen from 110 to 77 per cent., although the patient had been well throughout, and was not aware of any deterioration of her health.

The Iron Preparation and Dosage.-According to the practice of Witts and others, the preparation used in most of the cases has been the iron and ammonium citrate in doses of 90 grains aaily, increased to 120 grains and diminished to 60 grairs in single instances. Pilula ferri was given in one case up to a dose of 90 grains daily for six weeks ; the result did not appear to be so good as in cases treated with the scale preparation. No contraindication to these large doses has been met with ; some of the patients complain of flatulence, but this is a frequent complaint in this condition apart from the taking of iron; others complain of constipation, but it is not severe, and is easily counteracted by mild aperients. A full account of the value of different forms of iron is given by $\mathrm{I}$. J. Witts. ${ }^{2}$

The Changes in the Blood under Treatment.-There is a tendency in these cases to a high initial red cell count, 
with the development of an erythrocytosis under treatment. Five million per c.mm. being taken as a normal maximum (though this is considered high for women by some workers), three cases showed an erythrocytosis actually before treatment with massive doses of ironCases II, IV, and VI; and two (Cases V and VII) had counts of a normal figure. In all the cases (except Cases III and VI) iron had been given in small doses before the massive doses were begun. Smaller doses may be sufficient to stimulate red cell formation, though inadequate for hacmoglobin manufacture. The erythrocytosis was more than a transitory feature, persisting in two cases for more than thirteen months; in one case it reached the maximum recorded as early as six weeks. During the period of haemoglobinaemia the red cells show much anisocytosis and poikilocytosis, with many microcytes; but during a remission the cells are of normal average diameter. The haemoglobin increase that follows massive doses of iron may begin within the first two or three weeks (an increase of 25 per cent. in three weeks occurred in Case III), but the maximum increase lags behind the maximum red cell count for three or four months. The colour index, which is extremely low before treatment, has not been recorded as unity in any one of these cases, even after long treatment; the highest figure was 0.96 in Case I. The white cells show no change either in the total or differential counts.

The following are the clinical histories and blood records of nine cases. Six of these are typical of the condition, in which complete remissions were obtained under treatment. Most of the cases are still under observation.

\section{CASE I}

A spinster, aged 41 , had severe anaemia in 1918 at the age of 29; she had probably had some degree of anaemia for years previously. All her life she had suffered from neglected constipation, with a tendency to slight haemorrhages from the bowel. She was treated for "colitis" in 1920 with appendicostomy-closed in a few weeks. Blceding piles removed in 1925. Transfusions for anaemia in 1927 and 1928. Slight recurrent febrile. attacks with colitis during 1928 and 1929 ; symptoms were abdominal pain, flatulence, glossitis, and dysphagia. Menses fairly regular, no excessive loss.

Examination in August, 1929.- Nutrition fair, fissures at corners of mouth, papillae of tongue atrophied, tongue sore, pain and difficulty in swallowing, spleen not felt, liver normal. Sigmoidoscopy-no ulceration seen. Large uterine fibroid, no haemorrhage. Wassermann reaction negative. Test mealsecretion obtained by vomiting one hour after usual gruel meal -nearly pure mucus, complete achlorhydria, low chlorides. In hospital five months with continued low fever; treatment with large doses of anti-dysenteric serum caused high temperature reaction, and was followed by improvement in bowel symptoms and normal temperature. No improvement in blood condition during four months following; immediate improvement with massive iron; no relapse in anaemia or bowel symptoms after fifteen months. Still takes iron regularly.

\begin{tabular}{|c|c|c|c|c|}
\hline & & R. B. C. & $\mathrm{Hb}$ & C. I. \\
\hline $8 / 6 / 27$ & Before first blood transfu ion & $\underset{2.82}{\operatorname{Millini}}$ & Per cent. & 0.66 \\
\hline $3 / 3 / 28$ & Before second blood transfusion ... & 4.47 & 32 & $0.3 \hat{\jmath}$ \\
\hline $9 / 8 / 28$ & After five months liq. ferri perchlor. & 5.13 & 68 & 0.6 \\
\hline $9 / 10 / 28$ & Liver $6 \mathrm{oz}$. and $\mathrm{HCl}$ and $\mathrm{Fe} \ldots$ & 4.81 & 51 & 0.5 \\
\hline $7.10 / 23$ & $\begin{array}{l}\text { After two months hospital treat- } \\
\text { ment for colitis }\end{array}$ & 5.28 & 38 & c.36 \\
\hline $16 / 4 / 30$ & $\begin{array}{llll}\text { Before massive iron } & \ldots & \ldots & \ldots\end{array}$ & 5.5 & 44 & 0.4 \\
\hline $5 ; 5 / 30$ & After nineteen davs' treatment $\ldots$ & 5.8 & 58 & C.5 \\
\hline $8 / 9 / 30$ & Iron continued $\ldots . \quad \ldots$ & 6.2 & 96 & 0.7 \\
\hline 5. $12 / 20$ & $\begin{array}{lllll}\text { Ditto } \ldots & \ldots & \ldots & \ldots & \ldots\end{array}$ & 5.65 & 106 & 0.94 \\
\hline $4 / 5.31$ & $\begin{array}{l}\text { Iron for two weeks eac'l month } \\
\text { since March 3:th }\end{array}$ & 5.9 & 98 & 0.8 \\
\hline
\end{tabular}

\section{CASE II}

A married woman, aged 49. Four chi'dren, youngest 16 "Anaemia" since 14 years old ; "heart troub!" since the war; for past two years breathless, choking, and giddy on exertion, but still keeps house for family of eight. Appetite very poor, occasional indigestion. Menses always rather profuse, and during first six months of 1929 loss more severe, but no period for ten weeks before admission. First seen August, 1929. Thin, tongue smooth, not sore, very septic teeth, heart dilated, no valvular disease, spleen not felt, liver normal. Fractional meal-much mucus, complete achlorhydria.

\begin{tabular}{|c|c|c|c|c|}
\hline & & R. B. C. & $\mathrm{Hb}$ & C. I. \\
\hline 22.7/29 & Be:ore treatment & $\underset{4.13}{\text { Millions }}$ & $\begin{array}{c}\text { Per } c \in n t \\
28\end{array}$ & 0.3 \\
\hline 25/11/29 & $\begin{array}{l}\text { After three months' hospital treat- } \\
\text { ment, iron mixtures, liver, HCl, } \\
\text { arsenic }\end{array}$ & 4.85 & 38 & 0.7 \\
\hline 1:4/30 & $\begin{array}{l}\text { Fe. am. cit., } 60 \text { grains for four days } \\
\text { a }\end{array}$ & 6.2 & 55 & 0.5 \\
\hline $23 / 5 / 30$ & Ditto 90 grains from $24 / 430 \ldots$ & 6.3 & 78 & 0.6 \\
\hline 21:11:30 & $\begin{array}{l}\text { Fe omitted for time, but regular } \\
\text { since October } 2 \text { nd }\end{array}$ & 5.76 & 97 & 0.95 \\
\hline 22/3/31 & $\begin{array}{lllll} & \text { I e regularly } & \ldots & \ldots & \ldots\end{array}$ & - & $1: 5$ & - \\
\hline
\end{tabular}

\section{CASE III}

Married woman, aged 43. Three children, youngest 6 months. Severe haemorrhage with first confinement, but no abnormal loss with second and third ; " anaemia " with each. First seen February, 1930. Thin, spleen not felt. Wassermann reaction strongly positive. Fractional meal-much mucus, complete achlorhydria. Novarsenobillon injections (total $\mathbf{0 . 8}$ gram) given; treatment stopped on finding urobilin in the urine, and quinine-iodo-bismuth given. No improvement in anaemia could be ascribed to these drugs. Daily stomach lavage given for seventeen days, no concurrent improvement. Massive iron given, followed by rapid improvement.

\begin{tabular}{|c|c|c|c|c|c|c|}
\hline & & & & R. B. C. & $\mathrm{Hb}$ & C. I. \\
\hline $10 / 29$ & Soon after confinemeat & $\ldots$ & $\cdots$ & $\underset{1.85}{\text { Millions }}$ & $\begin{array}{c}\text { Per cent } \\
22\end{array} \mid$ & 0.6 \\
\hline $17: 3 / 30$ & Before massive iron & $\ldots$ &.. & 4.23 & 23 & 0.33 \\
\hline $18 / 2(3)$ & After five months' iron & $\ldots$ & $\ldots$ & 6.33 & 110 & 0.8 \\
\hline $12 ; 6 / 31$ & Iron omitled ten months & $\ldots$ & $\ldots$ & 4.73 & 77 & 0.8 \\
\hline
\end{tabular}

\section{CASE IV}

Married woman, aged 48. Three children, youngest 17 In 1928 first gastric symptoms; in 1929 attack of " gastric influenza "-that is, abdominal pain with vomiting and fever ; first seen three months later with complaints of flatulence and palpitations. Appetite fair, digestion usually good; diet includes meat and green vegetables. Menses normal, at six weeks' interval. Spleen not felt. Wassermann reaction negative. Fractional meal--resting juice some excess of mucus and pus, complete achlorhydria. Later, severe haemorrhage from uterine polyp, which was removed by operation; no further haemorrhage.

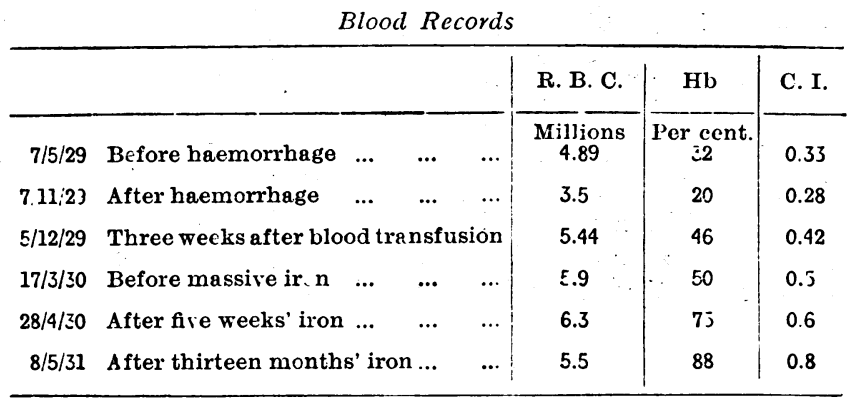

N.B.-Dose of ir:n 60 grains daily except for very short periods of 93 grains. Patient did not take larger dose wcll. 


\section{CASE $\mathrm{V}$}

Married woman, aged 41. Four children, youngest 9 When 33 years old was sent to sanatorium for tuberculosis no symptoms since. Appetite poor, flatulence slight, diet ordinary, including meat and green vegetables. Menorrhagia treated for two to three years, but menses natural for past six months. Thin, spleen not felt. Fractional meal-much mucus, complete achlorhydria, chlorides low. Very slight response to treatment with ordinary hospital iron mixtures good response to massive iron (see Table below).

\section{CASE VI}

Married woman, aged 35 . Three children-two living, agcd 12 and 10, one died at birth seven years ago. Four years ago "gastric influenza," details forgotten. Menses normal, but recently at two to three weeks' interval only. Duration of present symptoms four months; complains of " stomach pains and flatulence which keep her awake." Appetite good, takes ordinary food. No previous attack, never sore tongue. Spleen definitely palpable. Wassermann reaction negative. Fractional meal-complete achlorhydria, no excess of mucus. No previous treatments. Good response to massive iron (see Table).

Table showing Response to Massive Iron Dosage

\begin{tabular}{|c|c|c|c|c|c|c|c|}
\hline \multirow{3}{*}{ 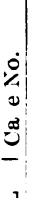 } & \multirow[b]{2}{*}{$\begin{array}{l}\text { Treatment before } \\
\text { Massive Iron }\end{array}$} & \multicolumn{6}{|c|}{ Blood Records } \\
\hline & & \multicolumn{2}{|c|}{$\begin{array}{c}\text { Minimum at } \\
\text { any Period }\end{array}$} & \multicolumn{2}{|c|}{$\begin{array}{c}\text { Immediately } \\
\text { before } \\
\text { Treatment }\end{array}$} & \multicolumn{2}{|c|}{$\begin{array}{l}\text { Maximum } \\
\text { during } \\
\text { Treatment }\end{array}$} \\
\hline & $\begin{array}{l}\text { Fe, liver, trans- } \\
\text { fusion }\end{array}$ & $\underset{22}{\mathrm{Hb}}$ & R. B. C. $_{3.6}$ & $\begin{array}{l}\text { Hb } \\
44\end{array}$ & R. B. C. & $\begin{array}{l}\mathrm{Hb} \\
106\end{array}$ & ${ }_{6.2}^{\text {R. B. C. }}$ \\
\hline 2 & Fe eight months & 28 & 4.18 & 56 & 6.2 & 105 & 6.5 \\
\hline 3 & Liver, N.A.B. & $\approx 2$ & 1.85 & 30 & 4.0 & 110 & 6.38 \\
\hline 4 & $\mathrm{Fe}, \mathrm{As}$, liver & 20 & 3.5 & 50 & 5.95 & 88 & 6.3 \\
\hline 5 & Fe six months & 3ิ & $4 . \varepsilon 5$ & 44 & 5.0 & 94 & 6.5 \\
\hline 6 & None & - & - & 60 & 5.9 & 110 & 6.75 \\
\hline
\end{tabular}

$\mathrm{Fe}=$ Iron in ordinary doses by mouth or subcutaneous injection.

$\mathrm{Hb}=$ Haemoglobin per cent., by Haldane's method.

R. B. C. = Red blood cells in millions per c.mm.

Massive iron $=\mathrm{Fe}$. am. cit. 9) grains daily, except in Cases iv and v. In Case iv 60 grains daily were given; in Case v 90 grains - but irregularly.

The minimum and maximum records only are given in the table; numerous other examinations were made, but not at sufficiently regular intervals to determine accurately the length of time required to obtain the maximum response to treatment. From the records, however, it is clear that the rise of haemoglobin to its maximum is much slower than that of the red cells. The red cell maximum was obtained after periods of treatment varying from six weeks to seven months, with an average for the six cases of four months; the haemoglobin maximum was recorded after periods varying from five to ten months, with an average of $\mathbf{7 . 3}$ months.

The following two cases are reported, one as showing an incomplete response after five months' treatment, and the other as failing to show any haemoglobin response at all. Both were treated as out-patients, and the cause of failure could not be fully investigated.

\section{CASE VII}

Spinster, aged 29. Not well since arthritis when 27 years old. Menses irregular, and scanty for five months. Fainting

\begin{tabular}{|c|c|c|c|c|}
\hline & & R. B. C. & $\mathbf{H b}$ & C. I. \\
\hline $28 / 3 / 33$ & Before treatment & $\underset{4.75}{\text { Millions }}$ & $\underset{38}{\text { Per cent. }}$ & 0.4 \\
\hline $29 / 4 / 30$ & After four weeks pil. ferri up to 90 & 4.83 & 58 & 0.6 \\
\hline $1 / 10 / 30$ & $\begin{array}{l}\text { Grains daily } \\
\text { grains daily }\end{array}$ & 4.82 & 80 & 0.8 \\
\hline
\end{tabular}

and gildiness; appetite capricious; eats very little meat; nausea and vomiting occasionally. On admission, nutrition fair, spleen not felt. Wassermann reaction negative. No arthritis, ten carious teeth extracted in hospital. Fractional meal-much mucus, hypochlorhydria.

\section{CASE VIII}

Married woman, aged 40. One child, aged 17. Anaemia after severe uterine haemorrhage in 1927 ; ill with diarrhoea and vomiting for one month, in October, 1929. Menses usually regular and scanty. Long history of "gastritis" haematemesis twenty years ago. Tongue sometimes sore, and easily irritated by condiments : corners of mouth cracked and sore. Often suffers from palpitation. No history of rheumatic fever. On examination nutrition fair, spleen not felt. Heart, well-compensated mitral stenosis with regurgitation, lesion of moderate severity. Wassermann reaction negative. Fractional meal-no excess of mucus, hypochlorhydria. Same report one year later.

Blood Records

\begin{tabular}{|c|c|c|c|c|c|c|c|}
\hline & & & & & R. B. C. & $\mathrm{Hb}$ & C. I. \\
\hline $12 / 5 / 30$ & Before treatment & $\ldots$ & $\cdots$ & $\ldots$ & $\underset{5.0}{\text { Millions }}$ & $\begin{array}{c}\text { Per cent. } \\
32\end{array}$ & 0.3 \\
\hline $5 / 6 / 30$ & Fe. am. cit. grains 90 & per $d a$ & & $\ldots$ & - & - & - \\
\hline $18 / 7 / 20$ & Aft:r six weeks' treat & ment & $\cdots$ & $\ldots$ & 3.9 & 28 & 0.4 \\
\hline $.5 / 12 / 3)$ & Taking Fe regularly & $\ldots$ & $\ldots$ & $\ldots$ & 4.85 & 44 & 0.45 \\
\hline $28 / 5 / 31$ & Ditto .. $\quad \ldots \quad \ldots$ & $\cdots$ & $\cdots$ & $\ldots$ & $5 . C 5$ & 36 & 0.36 \\
\hline
\end{tabular}

This patient constantly maintains that she feels very well, and has refused admission to hospital ; but there is no reason to doubt that she takes the dose of iron prescribed. The failure of the haemoglobin response is, however, complete.

\section{CASE IX}

Married woman, aged 35. Seven children, eldest 14. First seen January, 1927. History of post-partum haemorrhage with fifth confinement, and anaemia since. "Gastritis" at 14 years of age. A little vomiting with pregnancies, and one slight haematemesis ; a little bleeding from piles occasionally ; no menorrhagia; no excessive haemorrhage with later confinements. Is very breathless, and has giddy and fainting attacks during pregnancies. Examination-nutrition fair, liver and spleen not felt. Wassermann reaction negative. Fractional meal-much excess of mucus, complete achlorhydria.

In three and a half years of observation the highest haemoglobin record in this patient was 56 per cent., shortly after a blood transfusion; two further pregnancies occurred during that period. Massive iron was ordered during 1930 but the treatment was not continued, as the patient attends very irregularly, and always says that she feels " much better.'

\begin{tabular}{|c|c|c|c|c|}
\hline & & R. B. C. & $\mathrm{Hb}$ & C. $\mathrm{r}$. \\
\hline $4 / 1 / 27$ & Seven months pregrant & M 11 :ons & $\begin{array}{c}\text { Per cert } \\
40\end{array}$ & $0.4 t$ \\
\hline $11 / 3 / 27$ & Four weeks after confinement and & $4 . १ 4$ & 55 & $c .6$ \\
\hline $7 / 10 / 29$ & Diood transiusion & 3.19 & 20 & 0.3 \\
\hline $129 / 30$ & $\begin{array}{l}\text { Fourteen weeks pregnant, feeling } \\
\text { well }\end{array}$ & 4.52 & 40 & 0.44 \\
\hline
\end{tabular}

I am indebted to Dr. D. M. Vaux for the blood examinations, and to Dr. E. M. Martland for the test meal examinations.

\section{REFERENCES}

'Witts, I. J: Guy's Hospilal R.ports, July, 1930, 1xxx, 253.

Discussion, Section of Therapeutics, January 13th, 1931, Proc. Roy. Soc. Med., xxiv, No. 5, 545.

${ }^{3}$ Allbutt. Sir Clifford: "Chlorosis," Allbutt and Rolleston's System of Medicine, vol.., $\mathrm{v}$, $\mathrm{i} \mathbf{8 1}$ 